\title{
PELAKSANAAN PERATURAN PERUNDANG-UNDANGAN TENTANG TANGGUNGJAWAB AGEN PELAYARAN PT. ADMIRAL LINES SEBAGAI PENGANGKUT BARANG DALAM PERANGKUTAN LAUT DI PELABUHAN BELAWAN
}

\author{
Djafar Al Bram ${ }^{1}$
}

\begin{abstract}
Republic of Indonesia as the law country intends to create good national law an loyalty national needs which is based one the five principle of Indonesia and constitution 1945. It is however, its independence day, the legislation for national navigation has not been ever formed. The Indishe Scheepvaarswet Staablad 1936 No.700 still prevails based on article 2 for the transition regulation of Constitution 1945. In fact, the law product made by Deutche can fillow the present development related to national economy and navigation as one of very vital sea transportation in supporting either national or international trade. On such the case to anticipate the economy global in performing trade activity and to create such as the point, it is necessary tohave any upgrading, that is bay forming Constitution No. 21 of 1945 regarding the navigation it is expected, that such as the constitution can fulfill the present develoment and needs for transportation. In addition, it can and relationship among countries for achieving the national objectives based on the five principle of Indonesia and Constitution 1945. This research is intended to give answer regarding the responsibility of navigation company PT. Admiral Lines as the goods transport at Belawan harbour for any loss suffred by goods sender and receiver. Normative juridical and sociological jurudical approach are performend on this research and supported by primary and secondary data.
\end{abstract}

Keywords: trust, mutual benefit, compensation claims

\begin{abstract}
Abstrak
Republik Indonesia sebagai negara hukum menghendaki terwujudnya sistem hukum nasional yang mantap dan mengabdi kepada kepentingan nasional, bersumber pada Pancasila dan Undang-Undang Dasar 1945. Akan tetapi, sejak kemerdekaan Undang-Undang Pelayaran Nasional belum dapat dibentuk sehingga Indische Scheepvaarswet Staatsblad 1936 No. 700 masih diberlakukan berdasarkan Pasal 2 Aturan Peralihan Undang-Undang Dasar 1945. Namun pada kenyataannya produk hukum yang dibuat oleh Pemerintah Kolonial Belanda tersebut di atas selama ini sudah tidak dapat mengikuti perkembangan zaman, dikaitkan dengan perekonomian nasional dalam
\end{abstract}

\footnotetext{
${ }^{1}$ Penulis adalah Dosen Tetap Fakultas Hukum Universitas Borobudur Jakarta. Alamat kontak:
} 
hubungannya dengan Pelayaran sebagai salah satu sarana pengangkutan laut yang sangat vital dalam menunjang perdagangan nasional maupun internasional, oleh karenanya dalam rangka antisipasi globalisasi ekonomi dalam penyelenggaraan kegiatan perdagangan dan untuk mewujudkan hal-hal tersebut dipandang perlu untuk dilakukan pembaharuan yaitu dengan membentuk UndangUndang No.21 Tahun 1945 tentang Pelayaran yang dapat memenuhi perkembangan keadaan dan kebutuhan moda jasa transportasi sekaligus mempererat hubungan antara bangsa dalam usaha mencapai tujuan nasional yang berdasarkan Pancasila dan Undang-Undang Dasar 1945. Penelitian ini dimaksudkan untuk memberikan jawaban mengenai tanggung jawab perusahaan navigasi PT. Admiral Lines sebagai transportasi barang di pelabuhan Belawan atas kerugian yang diderita oleh pengirim dan penerima barang. Penelitian ini adalah penelitian yuridis normatif dengan pendekatan yuridis sosiologis dan didukung oleh data primer dan sekunder.

Kata kunci: kepercayaan, saling menguntungkan, tuntutan ganti rugi

\section{Pendahuluan}

Pada saat ini, sulit sekali bagi suatu negara untuk membangun perekonomian tanpa mengadakan kerjasama yang erat dengan negara-negara lainnya, hal mana seiring dengan semakin kompleksnya hubungan-hubungan atau transaksi ekonomi internasional dewasa ini yang mengakibatkan semakin kompleksnya aturan-aturan hukum pengangkutan yang perlu dipahami sebagai konsekuensi semakin meningkatkan transaksi perdagangan internasional khususnya dalan rangka penyelesaian sengketa-sengketa bisnis yang terjadi dalam pengangkutan barang intersuler maupun antar negara. apalagi menghadapi dan menyongsong Era Pasar Bebas (Asean Free Trade Area) yang semakin mendekati pelaksanaannya, maka dalam hal ini suka tidak suka dituntut percepatan pembangunan di segala bidang termasuk bidang Perdagangan Internasional terutama sektor pengangkutan dengan segala aspeknya.

Salah satu contoh adanya bentuk kerjasama perdagangan tersebut dapat dilihat dari hasil Tripartite Meeting 19 - 20 Juli 1993 di Langkawi Malaysia, dengan dibentuknya kerjasama Indonesia - Malaysia - Thailand Growth Treangle Project (IMT-GT) sebagai kerjasama di bidang ekonomi khususnya perdagangan ekonomi nasional. ${ }^{2}$

Pembangunan nasional membutuhkan jasa angkutan laut yang cukup serta memadai. Tanpa adanya taransportasi sebagai sarana penunjang tidak dapat diharapkan tercapainya hasil yang memuaskan dalam usaha pengembangan ekonomi dari suatu daerah kedaerah lainnya, dan dari suatu negara ke negara lainnya, dalam hal ini dapat dilihat pentingnya masalah

${ }^{2}$ M. Solly Lubis, Hukum Nasional Dalam Era PKPT II, Makalah Mata Kuliah Politik Hukum, Pascasarjana, Universitas Sumatera Utara, Medan, 1999, Hal. 2 
pengangkutan karena tidak hanya sebagai alat mobilitas warganya tetapi lebih dari itu juga merupakan penggerak roda pembangunan yang berdimensi sangat luas yaitu melayani barang dan jasa, merangsang (stimulating/promoting) pertumbuhan ekonomi di wilayah yang belum berkembang (ship promotes the trade), menunjang (sevicing/supporting), sektor perdagangan, ekonomi dan sektor lainnya (ship follow the trade), mendukung daya saing komoditas produksi nasional baik produksi dalam negeri maupun luar negeri serta sebagai sarana untuk memperkokoh persatuan dan kesatuan bangsa. Melihat besar dan pentingnya peranan tersebut, maka angkutan laut merupakan urat nadi kehidupan ekonomi, sosial, politik, budaya maupun Hankam negara kepulauan Indonesia. ${ }^{3}$

Pegangkutan diartikan sebagai pemindahan barang dan manusia dari tempat asal ke tempat tujuan, dalam hubungan ini terlihat adanya tiga hal yaitu:

(a) ada muatan yang diangkut;

(b) tersedianya sarana (kapal) sebagai alat angkutan; dan

(c) ada alur perairan yang dapat dilaluinya. ${ }^{4}$

Proses pengangkutan merupakan gerakan dari tempat asal, dimana kegiatan angkutan dimulai ke tempat tujuan, dan kemana kegiatan pengangkutan itu berakhir. Dengan adanya pengangkutan menyebabkan nilai barang lebih tinggi di tempat tujuan dari pada di tempat asal, dan nilai ini lebih besar dari pada biaya yang dikeluarkan untuk pengangkutannya, nilai yang berikan oleh pengangkutan adalah berupa nilai tempat (place utility) dan nilai waktu (time utility), kedua nilai ini diperoleh jika barang telah diangkut ketempat dimana nilainya lebih tinggi dan dapat di manfaatkan pada waktunya, pengangkutan memberikan jasa kepada masyarakat yang disebut dengan jasa angkutan sebagaimana sifatnya jasa-jasa lainnya yang merupakan hasil keluaran (output) perusahaan angkutan seperti jasa perusahaan pelayaran, jasa ini merupakan salah satu faktor-faktor masukan dari kegiatan perdagangan dan kegiatan ekonomi lainya.

Transportasi atau pengangkutan bermanfaat bagi masyarakat dalam arti hasil-hasil dan bahan-bahan baku dari suatu daerah dapat dipasarkan kepada perusahaan industri. Hasil-hasil barang jadi yang diproduksi oleh pabrik dijual oleh produsen kepada masyarakat atau perusahaan-perusahaan yang bergerak dalam bidang pemasaran. Dengan demikian pengangkutan adalah suatu kegiatan pemindahan barang dari suatu tempat ke tempat lainnya dengan dua unsur terpenting yaitu:

(a) pemindahan/pergerakan;

(b) secara fisik mengubah tempat dari barang ke tempat lainnya. ${ }^{5}$

${ }^{3}$ Sambutan Dirjen Hubla, Tjuk Sukardiman, Pada peluncuran buku, M. Huseyin Umar, "Hukum Maritim dan Masalah-masalah Pelayaran di Indonesia", Buku 3, (Jakarta: Pustaka Sinar Harapan, 2001), hal. vii.

${ }^{4}$ Abbas Salim, "Manajemen Pengangkutan Laut”, (Jakarta: Aksara, 1993), hal. 4. 
Mengingat pengangkutan ini tidak saja menyangkut transportasi dalam negeri, tetapi lebih jauh juga melintasi batas-batas negara, maka peranan hukum tentunya semakin penting. Hukum haruslah mampu menjawab semua persoalan yang mungkin timbul dalam aktivitas pengangkutan itu, walaupun pengangkutan meliputi pengangkutan darat, pengangkutan udara dan laut, maka dalam penulisan ini hanya dibatasi pada pengangkutan laut saja yaitu pengangkutan barang antar pulau (Intersuler) dan pengangkutan barang antar negara (Impor Ekspor) yang ditanganni pengangkutannya oleh Perusahaan Pelayaran PT. Admiral Lines di Pelabuhan Belawan.

Penyelesaian secara musyawarah adalah cara awal yang dipakai kedua belah pihak dalam menyelesaikan tuntutan sengketa ganti rugi, penyelesaian melalui forum musyawarah dan mufakat adalah bentuk penyelesaian sengketa ganti rugi antara pihak pengangkut dan pengirm serta penerima barang, karena dengan bentuk penyelesaian seperti ini maka permasalahan sengketa tuntutan ganti rugi akan dapat diselesaikan secara cepat murah, dan tidak menimbulkan ketersinggungan antara kedua bela pihak, dengan kata lain penyelesaian bisa lebih efektif dan ekonomis.

\section{Pengangkutan Barang}

Sebelum membahas lebih mendalam mengenai pengangkutan barang melalui laut, maka perlu kiranya menentukan terlebih dahulu tentang pengertian atau definisi tentang pengangkutan, agar dengan definisi tersebut tersimpul suatu kepastian dan kesatuan yang lebih jelas mengenai pengertian di dalam pembahasan selanjutnya, menurut arti katanya, pengangkutan berasal dari kata "angkut" yang berarti angkat dan bawa, muat dan bawa atau kirimkan, dengan demikian istilah pengangkut artinya sama dengan mengangkat dan membawa, memuat dan membawa atau mengirimkan.

Selanjutnya beberapa sarjana memberikan pengertian pengangkut sebagai berikut:

\section{Abdulkadir Muhammad}

Pengangkutan artinya pengangkatan dan pembawaan barang atau orang, pemuatan dan pengiriman barang atau orang, jadi dalam pengertian pengangkutan ini tersimpul suatau proses kegiatan atau gerakan pengangkutan barang dari suatu tempat ke tempat lainya. ${ }^{6}$

\section{Radiks Purba}

${ }^{5}$ Abbas Salim, H. A, "Manajemen Pelayaran Niaga dan Pelabuhan”, (Jakarta: Pustaka Jaya, 1995), hal. 10-11.

${ }^{6}$ Abdulkadir Muhammad, "Hukum Pengangkutan Darat, Laut dan Udara", (Bandung: Cipta Aditya Bakti, 1994), hal. 19. 
Pengangkut artinya mengangkat barang dan penumpampang dari suatu pelabuhan ke pelabuhan lain dengan menggunakan alat pengangkutan laut (kapal). ${ }^{7}$

\section{Muchtaruddin Siregar}

Pengangkutan diartikan sebagai pemindahan barang dan manusia dari tempat asal ke tempat tujuan, jadi ada muatan yang diangkut tersedianya kapal sebagai sarana pengangkutan, dan ada alur perairan laut yang dilaluinya yang dimulai dari tempat tujuan dan sampai kemana kegiatan pengangkutan laut diakhiri. ${ }^{8}$

\section{HMN Purwosutjipto sebagaimana dikutip H. Hasnil Basri Siregar}

Pengangkutan adalah perjanjian timbal balik antara pengangkut dengan pengirim, dimana pengangkut mengikatkan diri untuk menyelenggarakan pengangkutan barang atau orang dari suatu tempat ke tempat tujuan dengan selamat, sedangkan pengirim mengikatkan diri untuk membayar uang angkutan (freight). ${ }^{9}$

\section{FDC. Sujatmiko}

Pengangkutan barang melalui laut diberikan suatu istilah dengan pelayaran niaga, yang mendefinisikan sebagai "usaha pengangkutan barang khususnya barang dagangan melalui laut, baik dilakukan antar tempat-tempat pelabuhan-pelabuhan dalam wilayah sendiri maupun antar negara. ${ }^{10}$

Berdasarkan pengertian definisi yang ada tentang pengangkutan tersebut, maka dapat ditarik suatu kesimpulan tentang pengertian hukum dari pengangkutan itu sendiri yaitu: pengangkutan tidak lain adalah: sebuah perjanjian timbal balik pada mana pihak pengangkut mengikat diri untuk menyelenggarakan pengangkutan barang dan atau orang ke tempat tujuan pelabuhan bongkar tertentu sebagaimana tercantum dalam dokumen pengangkutan yaitu: $B / L$ (Bill of Lading), sedangkan pihak lainya pengirim atau penerima, berkewajibann untuk menunaikan pembayaran biaya angkut (Freight Cost).

\section{8}

${ }^{7}$ Radiks Purba, “Angkutan Muatan Laut”, Cetakan I, (Jakarta: Rineka Cipta, 1997), hal.

${ }^{8}$ Muchtaruddin Siregar, "Beberapa Masalah Ekonomi dan Manajemen Pengangkutan", (Jakarta: Lembaga Peneliti, Fakultas Ekonomi Universitas Indonesia, 1990), hal. 3.

${ }^{9}$ H. Hasnil Basri Siregar, "Kapita Selekta Hukum Laut Dagang", Kelompok Studi Hukum dan Masyarakat, Fakultas Hukum Universitas Sumatera Utara, (Medan: TNT Victory Printing, 1993), hal. 2.

${ }^{10}$ Soedjatmiko, FDC, "Pokok-pokok Pelayaran Niaga", (Jakarta: Akademi Presindo, 1985), hal. 1. 
Kemudian masalah pengangkutan laut itu sendiri dapat dilihat dari dua sudut pandang yaitu:

1. Angkutan laut sebagai salah satu kegiatan angkutan barang atau penumpang dengan menggunakan kapal laut, dari satu pelabuhan ke pelabuhan lainnya. Hasil akhir dari kegiatan ini adalah perpindahan barang atau penumpang dari pelabuhan asal ke pelabuhan tujuan.

2. Angkutan laut sebagai salah satu bidang kegiatan usaha jasa yang dilakukan oleh seorang atau sekelompok orang atau badan hukum yang menyediakan atau memberikan jasa angkutan laut kepada orang lain yang membutuhkannya. ${ }^{11}$

Dilihat dari sudut pandang pertama, dengan berpindahnya barang dari suatu tempat ke tempat lainya, maka barang tersebut akan lebih berguna atau akan memperoleh nilai tambah dibandingkan tempat asalnya, setidak-tidaknya itulah yang diharapkan oleh pemilik barang atau pengguna jasa angkutan laut. Dari sudut pandang kedua, angkutan laut dilihat sebagai bidang jasa yang sudah banyak dilakukan oleh Pengusaha Nasional Indonesia (Perusahaan Pelayaran Nasional).

\section{Perjanjian Pengangkutan}

Perjanjian merupakan salah satu transaksi yang telah sering dilakukan dalam kehidupan sehari-sehari dan hampir setiap kegiatan dilakukan dengan janji. Perjanjian adalah suatu peristiwa dimana seorang barjanji kepada orang lain atau dimana dua orang saling berjanji untuk melaksanakan suatu hal. ${ }^{12}$ Berdasarkan rumusan tersebut di atas, diketahui bahwa yang dimaksud dengan perjanjian adalah suatu peristiwa dimana seorang mengikatkan diri kepada orang lain atau dua orang saling berjanji untuk melaksanakan suatu hal yang telah disepakati bersama.

Untuk memberikan pengertian yang lengkap tentang istilah perjanjian pengangkutan dapat dikemukakkan beberapa pendapat para sarjana yaitu:

\section{Purwosutjipto}

Perjanjian pengangkutan ialah sebuah perjanjian timbal balik pada mana pihak pengangkut mengikatkan diri untuk menyelenggarakan pengangkutan barang atau dan orang ke tempat tujuan tertentu, sedangkan pihak lainnya (pengirim sebagai penerima, pengirim atau penerima, penumpang) berkeharusan untuk menunaikan pembayaran biaya tertentu untuk pengangkutan tersebut. ${ }^{13}$

11 Haryanto Danutirto, Menteri Perhubungan RI, Sambutan Dalam Seminar Tentang Pelaksanaan Undang-Undang No. 21 Tahun 1992, Jakarta, 19 Oktober 1998

${ }^{12}$ R. Subekti, "Pokok Hukum Perdata", (Jakarta: PT. Internusa, 1979), hal. 1. 


\section{R. Subekti}

Memberikan suatu pembatasan masalah perjanjian pengangkutan, disebutkannya bahwa perjanjian pengangkutan dimana satu fihak menyanggupi untuk dengan aman membawa orang atau barang dari suatu tempat ke tempat lainnya, sedangkan fihak yang lainnya menyanggupi akan membayar ongkos barangnya ${ }^{14}$

3. Perjanjian pengangkutan menurut The Hague Rules Article 1 ad (b) menyatakan bahwaperjanjianengangkutan hanya memakai perjanjian pengangkutan yang ditutup oleh konosemen atau dokumen sejenis, sejauh dokumen tersebut berhubungan dengan pengangkutan barangbarang melalui laut, juga berlaku terhadap konosemen atau dokumen sejenis yang berdasarkan piagam dari sutau peristiwa yang alat-alatnya berhubungan antara alat angkutan dengan pemiliknya. ${ }^{15}$

4. Konvensi Hamburg tahun 1978 menyatakan:

Perjanjian pengangkutan laut berati perjanjian dimana pengangkut membayar ongkos tambang untuk membawa barang melalui laut dari suatu pelabuhan ke pelabuhan lain, bagaimanapun perjanjian yang meliputi pengangkutan laut dan juga beberapa pengangkutan yang lain berati dianggap menjadi perjanjian pengangkutan laut hanya bertujuan sebagai alat pengangkutan laut. ${ }^{16}$

Dalam membuat suatu perjanjian harus dengan kemauan yang bebas dari kedua belah pihak untuk mengikat diri, kemampuan yang bebas ini merupakan salah satu syarat mutlak dalam setiap membuat perjanjian. Setiap perjanjian yang di buat secara sah berlaku sebagai undang-undang bagi para pihak yang telah membuatnya, oleh karena itu para pihak harus mematuhi isi dari perjanjian tersebut. Hal ini diatur dalam pasal 1338 ayat (1) KUH perdata yang berbunyi: "Perjanjian yang dibuat secara sah berlaku sebagai undang-undang bagi mereka yang membuatnya".

Dilihat dari sifatnya perjanjian antara pengirim dengan perusahaan pengangkutan merupakan suatu perjanjian untuk melakukan jasa tertentu, yaitu untuk mengangkut barang, sehingga apa yang telah dijanjikan dapat dilaksanakan dengan baik dan mencapai hasil sebagaimana yang diharapkan. Perjanjian adalah cukup dengan dicapainya kata sepakat mengenai hal-hal pokok dari perjanjian tersebut dan perjanjian itu sudah dilahirkan pada saat atau detik tercapainya konsensus, pada detik itu sudah sah dan mengikat. Apabila antara kedua belah pihak telah tercapai kesepakatan terhadap hal-hal

${ }^{13}$ R. Soekardono, "Hukum Dagang Indonesia”, Jilid 2, (Jakarta: Rajawali Press, 1981, hal. 8 .

${ }^{14}$ R. Subekti, “Aneka Perjanjian”, (Bandung: Alumni, 1982), hal. 81.

${ }^{15}$ Wiwoho Soedjono, 'Hukum Dagang”, (Jakarta: Bina Aksara, 1982), hal. 33.

${ }^{16}$ Ibid., hal. 34 . 
pokok yang mereka kehendaki bersama, mengandung arti bahwa pihak yang satu, yaitu perusahaan pengangkutan telah menyanggupi untuk memenuhi permintaan pihak yang lain yaitu pengirim untuk mengangkut barang dari tempat pemuatan ke daerah tujuan yang telah ditentukan dan pengirim telah menyanggupi untuk membayar ongkos pengangkutan.

Dengan demikian pengangkutan laut adalah suatu pekerjaan tertentu yang harus di penuhi terhadap pihak yang membutuhkannya dengan pemberian biaya pengangkutan. Pekerjaan itu dilakukan dengan waktu yang tertentu yang telah disepakati bersama. Apabila pada saat yang telah ditentukan pihak pengangkut dapat menunaikan prestasi dengan baik dan pihak pemakai jasa merasa puas, maka ia akan tetap mempergunakan jasa pengangkutan dari perusahaan tersebut. Terjadinya perjanjian pengangkutan karena adanya persetujuan ini jelas tidak dilakukan secara sepihak, harus ada persesuaian kehendak dari kedua belah pihak.

\section{Tanggungjawab Pengangkut}

Dalam satu perjanjian pengangkutan melalui laut, faktor tanggung jawab pihak pengangkut adalah merupakan suatu hal yang sangat penting. Hal ini adalah logis karena walau bagaimana si pemilik barang harus mendapat jaminan dari pengangkut tentang kesanggupannya untuk menjamin barang yang dikirimkannya sesuai dengan perjanjian pengangkutan.

Menurut pasal 7 PP nomor 17 tahun 1988, menyebutkan bahwa:

Perusahaan pelayaran bertanggung jawab sebagai pengangkut penumpangBarang dan hewan sesuai dengan ketentuan peraturan perundang-undangan Yang berlaku atau persyaratan perjanjian pengangkutan atau kelaziman yang Berlaku dalam bidang pelayaran.

Menurut ketentuan ini pengangkut bertanggung jawab menurut ketentuan peraturan perundang-undangan, menurut perjanjian seperti yang disebutkan dalam syarat-syarat dalam konosemen, dan kebiasaan-kebiasaan yang timbul dalam bidang pelayaran.

Menurut pasal 447 KUHD disebutkan bahwa:

Si pengangkut bertanggung jawab untuk kerugian yang disebabkan karena terlambat diserahkannya barang yang diangkutnya, kecuali apabila dibuktikanya, bahwa kelambatan kapal itu disebabkan karena suatu malapetaka, yang selayaknya tidak dapat dicegah atau dihindarkannya.

Menurut ketentuan diatas tugas dan tanggung jawab pengangkut dalam membawa dan menyerahkan barang angkutan dengan selamat di tempat tujuan haruslah tepat pada waktu yang telah diperjanjikan. Ketentuan ini sampai pada 
masa sekarang ini berlaku dan di patuhi oleh para pihak dan dalam prakteknya pengangkutan barang saat ini.

Dalam pasal 468 ayat 2 KUHD, menyebutkan bahwa:

Si pengangkut diwajibkan mengganti segala kerugian yang disebabkanKarena barang tersebut seluruhnya atau sebagian tidak dapat diserahkannya, atau karena terjadi kerusakan pada barang itu, kecuali apabiladisebabkan oleh suatu malapetaka yang selayaknya tidak dapat dicegahkesalahan dari yang mengirimkanya.

Dalam ketentuan ini disebutkan tidak dapat dicegah maupun dihindarkan secara layak. Untuk menentukan penghindaran secara layak atau tidaknya, dalam hal ini juga masih terdapat keraguan, karena perkataan secara layak, maka pertanggung jawaban si pengangkut tergantung pada keadaan dan atas kejadian yang tidak dapat dipastikan terlebih dahulu, sehingga merupakan pertanggung jawaban secara relatif, karena dalam hai ini masih tergantung pada kemampuan dan keadaan kapal yang mengangkut dalam menghadapi keadaan yang tidak dapat di hindarkan (forcer majeur)

Pengangkut bertanggung jawab untuk perbuatan dari segala mereka yang dipekerjakanya, dan untuk segala benda yang dipakainya dalam menyelenggarakan pengangkutan tersebut. Berdasarkan ketentuan ini, maka pihak pengangkut harus bertanggung jawab terhadap:

1. Segala perbuatan mereka yang dipekerjakan bagi kepentingan pengangkutan itu. Dalam hal ini anak buah kapal, dalam hal kerusakan barang itu dilakukan oleh stevedore (perusahaan bongkar muat) sewaktu memuat atau membongkar barang, pihak pengangkut juga harus mempertanggung jawabkan kerusakan itu, dan berkewajiban mengganti kerugian jika ada claim dari pihak pemilik barang. Hal ini adalah logis karena pemilik barang hanya ada hubungan hukum dengan pihak pengangkut dan tidak ada hak untuk mengajukan claim pada pihak stevedore, sebaiknya yang dapat mengajukan claim atas kerusakan barang itu kepada stevedore adalah pihak pengangkut, karena antara pihak stevedore dan pengangkut terdapat perjanjian bongkar muat barang.

2. Segala barang (alat-alat yang dipakai untuk menyelenggarakan pengangkutan).

Dalam hal ini misalnya saja, derek (sling) yang dipergunakan itu lepas sewaktu mengangkut dari kade ke dalam palka sehingga barang yang diangkut itu jatuh ke laut dan rusak, maka dalam hal ini si pengangkut juga harus bertanggung jawab terhadap kerusakan itu.

Demikian juga dengan tanggung jawab pengangkutan, seperti di ketahui pengangkutan berusaha mengurangi tanggung jawabnya dalam pengiriman barang-barang matan itu sedapat mungkin dalam menghadapi risiko yang mungkin terjadi. 
3. Bahwa pihak perusahaan pengangkut juga bebas dari tanggung jawab apabila barang yang dikirimkan pihak pengirim itu pengepakkannya tidak baik atau tidak sempurna, sehingga sewaktu dimuat dan disatukan dengan barang lain rusak. Jadi dalam hal terjadinya pengirim barang itu apabila kesalahan dari pihak pengirim barang itu sendiri, maka pihak pengangkut bebas dari tanggung jawab. Misalnya, pengirim mengirimkan porselen dan pengepakanya tidak baik, sewaktu dimuat di atas porselen itu diletakan barang pecah belah, oleh karena pengepakanya tidak sempurna porselen yang dikirimkan itu pecah, maka dalam hal ini pengangkut tidak bertanggung jawab atas kerusakan itu.

\section{Ganti Rugi}

Dalam pasal 468 KUHD disebutkan bahwa:

Si Pengangkut di wajibkan mengganti segala kerugian yang di sebabkan karena barang tersebut seluruhnya atau sebagian tidak dapat diserahka atau karena terjadi kerusakan para barang itu, kecuali apabila dibuktikan bahwa tidak diserahkan barang atau kerusakan tadi, disebabkan oleh suatu malapetaka yang selayaknya tidak dapat dicegah maupun dihindarinya, atau cacat daripada barang tersebut, atau oleh kesalahan dari pengirim.

Jadi menurut pasal ini yang menentukan bahwa pengangkut diwajibkan mengganti segala kerugian yang disebabkan karena:

1. Barang muatan seluruhnya atau sebagian tidak dapat diserahkan kepada penerima (barang hilang, terbakar, musnah, tenggelam, dicuri orang, dan lain-lain)

2. Barang muatan itu seluruhnya atau sebagian rusak, sedangkan seandainya pihak pengangkut dapat membuktikan bahwa tidak diserahkannya atau kerusakannya barang itu karena:

a. Oleh suatu malapetaka yang selayaknya bahwa tidak dapat dicegah ataupun dihindarkan.

b. Adanya sifat, keadaan atau suatu cacat dari pada barang muatan itu sendiri.

Misalnya, pemillik kopi hendak mengirimkan kopi dari Belawan ke Rotterdam. Kopi dikemas dengan kayu yang cukup rapat. Karena kemasan begitu rapat sehingga menyebabkan kelembaban dalam kemasan dan karena lembabnya kemasan mengakibatkan mutu kopi berkurang. Terhadap hal-hal diatas ini pihak pengangkut dapat dibebaskan dari tanggung jawabnya.

3. Disebabkan karena kesalahan atau kelalaian Ekspeditur atau pengirim, misalnya saja dalam hal ini si pengirim barang itu tidak menjelaskan, 
keadaan barang yang sebenarnya untuk menghindari uang tambang yang tinggi, dan apabila terjadi kerusakan pada barang tersebut pihak pengangkut tidak bertanggung jawab.

Berdasarkan penelitian terhadap 10 (sepuluh) Perusahaan Pelayaran terdapat keterlambatan barang sebagaimana tabel tersebut di bawah ini:

TABEL I

Risiko Keterlambatan yang Dialami Perusahaan Pelayaran Dalam pengangkutan baranng

\begin{tabular}{|c|l|c|c|}
\hline NO. & \multicolumn{1}{|c|}{ Katagori } & frekuens & \% \\
\hline 1. & Kerusakan barang & 10 & 20,83 \\
2. & Kekurangan barang & 12 & 25,00 \\
3. & Kerusakan barang & 16 & 33,34 \\
4. & Keterlambatan barang & 10 & 20,83 \\
\hline & Jumlah & $\mathbf{4 8}$ & $\mathbf{1 0 0 , 0 0}$ \\
\hline
\end{tabular}

Sumber: Data Primer

Risiko yang sama juga diakui oleh Perusahaan Ekspedisi Muatan Kapal Laut (EMKL), dimana berdasarkan pengalaman perusahaan selama menjalankan kegiatannya usahanya, seluruh responden mengalami risiko barang susut, berkurang, rusak dan terlambat sebagaimana diperlihatkan dalam tabel berikut ini:

TABEL II

Risiko Barang Susut, Kurang, Rusak dan Terlambat Yang Dialami Perusahaan EMKL

\begin{tabular}{|c|l|c|c|}
\hline No. & \multicolumn{1}{|c|}{ Kategori } & Frekuensi & $\%$ \\
\hline 1 & Ya & 40 & 80,00 \\
2 & Tidak & 10 & 20,00 \\
\hline & Jumlah & $\mathbf{5 0}$ & $\mathbf{1 0 0 , 0 0}$ \\
\hline
\end{tabular}

Sumber: Data primer

Selanjutnya perusahaan pelayaran mengakui kesusutan barang, mereka tidak bertanggung jawab sama sekali, alasannya adalah kesusutan barang memang dapat dilepaskan dari tanggung jawab yuridis sepanjang kesusutan itu memenuhi ambang batas tertentu. Sedangkan untuk kekurangan barang 
sebanyak 10 (sepuluh) perusahaan pelayaran mengakui akan bertanggung jawab dan 10 (sepuluh) perusahaan pelayaran mengakui pula bahwa mereka juga bertanggung jawab kerusakan barang, sedangkan 2 (dua) perusahaan pelayaran lainya mengakui bertanggung jawab atas keterlambatan sampainya barang, hal ini dapat diperlihatkan oleh tabel sebagai berikut:

TABEL III

Tanggung jawab Perusahaan Pelayaran Terhadap Risiko Barang Yang Diambil

\begin{tabular}{|l|l|c|c|}
\hline No. & \multicolumn{1}{|c|}{ Kategori } & Frekuensi & $\%$ \\
\hline 1. & Kesusutan barang & 3 & 12,00 \\
2. & Kekurangan barang & 10 & 40,00 \\
3. & Kerusakan barang & 10 & 40,00 \\
4. & Keterlambatan barang sampai & 2 & 08,00 \\
\hline & Jumlah & $\mathbf{2 5}$ & $\mathbf{1 0 0 , 0 0}$ \\
\hline
\end{tabular}

Sumber: Data Primer

Pengalaman pihak perusahaan pelayaran dalam mengangkut barangbarang yang paling banyak adalah kerusakan barang yaitu 10 (sepuluh) perusahaan tau sekitar $40 \%$, sebaiknya mengakui bahwa kekurangan barang dan keterlambatan sampai barang yang paling sering mereka alami sebagaimana diperlihatkan tabel berikut ini:

TABEL IV

Risiko Barang Yang Paling Banyak Diderita Oleh Perusahaan Pelayaran

\begin{tabular}{|l|l|c|c|}
\hline No. & \multicolumn{1}{|c|}{ Katagori } & Frekuensi & \% \\
\hline 1. & Kesusutan barang & 2 & 10,52 \\
2. & Kekurangan barang & 8 & 42,11 \\
3. & Kerusakan barang & 7 & 36,85 \\
4. & Keterlambatan & 2 & 10,52 \\
\hline & Jumlah & 19 & $\mathbf{1 0 0 , 0 0}$ \\
\hline
\end{tabular}

Sumber: Data Primer

Risiko yang diterima oleh pihak pemillik yang dalam hal ini diwakili oleh perusahaan EMKL, sering pula berakibat timbulnya claim. Ternyata 
semua perusahaan pelayaran mengakui pernah di claim oleh pihak pemilik barang, sebagaimana diperlihatkan pada tabel berikut ini:

TABEL V

Claim Terhadap Peristiwa Risiko Barang Yang Diangkut Oleh

Perusahaan Pelayaran

\begin{tabular}{|l|l|c|c|}
\hline No. & \multicolumn{1}{|c|}{ Katagori } & Frekuensi & \% \\
\hline 1. & Penah di Claim & 10 & 100,00 \\
2. & Tidak pernah di Claim & 0 & 0,00 \\
\hline & Jumlah & $\mathbf{1 0}$ & $\mathbf{1 0 0 , 0 0}$ \\
\hline
\end{tabular}

Sumber: Data Primer

Ketika hal tersebut dikonfirmasikan dengan data dari perusahaan EMKL, kesimpulan yang sama juga dapat dibuktikan. Ternyata seluruh perusahaan EMKL pernah mengclaim pihak perusahaan pelayaran untuk bermacammacam risiko yang diderita oleh pihaknya sebagaimana diperlihatkan pada tabel dibawah ini:

TABEL VI

Claim Perusahaan EMKL Terhadap Perusahaan Pelayaran

\begin{tabular}{|l|l|c|c|}
\hline No. & \multicolumn{1}{|c|}{ Katagori } & Frekuensi & $\%$ \\
\hline 1. & Pernah di claim & 10 & 100,00 \\
2. & Tidak pernah di claim & 0 & 0,00 \\
\hline & Jumlah & $\mathbf{1 9}$ & $\mathbf{1 0 0 , 0 0}$ \\
\hline
\end{tabular}

Sumber: Data Primer

Selanjutnya cara-cara penyelesaian claim tersebut ternyata pula ditempuh dengan 3 (tiga) cara yaitu melalui musyawarah mufakat antara kedua belah pihak, melalui musyawarah memakai forum arbitrase dan melalui peradilan formal sebagaimana diperlihatkan pada tabel berikut ini:

TABEL VII

Cara-cara Penyelesaian Yang Ditempuh

\begin{tabular}{|l|l|c|c|}
\hline No. & \multicolumn{1}{|c|}{ Katagori } & Frekuensi & \% \\
\hline 1. & $\begin{array}{l}\text { Melalui musyawarah mufakat } \\
\text { antara kedua belah pihak }\end{array}$ & 16 & 84,22 \\
2. & $\begin{array}{l}\text { Melalui musyawarah dengan } \\
\text { memakai pihak arbitrase }\end{array}$ & 3 & 15,78 \\
3. & Melalui peradilan formal & 0 & 0,00 \\
\hline & Jumlah & $\mathbf{1 9}$ & $\mathbf{1 0 0 , 0 0}$ \\
\hline
\end{tabular}

Sumber: Data Primer 
Bedasarkan tabel diatas, ternyata bahwa cara musyawarah mufakat adalah cara yang paling banyak ditempuh oleh parah pihak. Hal ini juga sejalan dengan pengakuan pihak EMKL yang hanya 3 (tiga) atau $5,66 \%$ yang mengajukan penyelesaian claim melalui lembaga arbitrase sebagaimana diperlihatkan pada tabel berikut:

TABEL VIII

\begin{tabular}{|l|l|c|c|}
\hline No. & \multicolumn{1}{|c|}{ Katagori } & Frekuensi & $\%$ \\
\hline 1. & Melalui musyawarah mufakat & 50 & 94,34 \\
2. & Melalui pihak arbitrase & 3 & 5,66 \\
\hline & Jumlah & $\mathbf{5 3}$ & $\mathbf{1 0 0 , 0 0}$ \\
\hline
\end{tabular}

Sumber: Data Primer

Ternyata pilihan terhadap musyawarah ini bukanlah pilihan yang tanpa makna, oleh karena masing-masing pihak telah memberikan suatu alasan bahwa dengan cara musyawarah dan mufakat para pihak dapat menyelesaikan permasalahan mereka secara cepat, murah dan tidak menimbulkan ketergantungan antara kedua belah pihak. Kerugian-kerugianpun bisa dipikul secara bersama dengan kata lain penyelesaiannya bisa lebih efektif dan lebih ekonomis dan lebih terarah jika dibandingkan dengan cara penyelesaian melalui peradilan formal.

\section{Musyawarah}

Pada dasarnya tidak seorang/satu pihak pun yang menginginkan adanya/ terjadinya suatu sengketa terhadap apa yang telah disepakati (dalam kontrak) dengan pihak lainya. Namun demikian, haruslah dimaklumi bahwa terjadinya sengketa tidak jarang terjadi, hanya karena hal-hal yang sangat sepele. Untuk itu, bagi para perancang/pembuat kontrak haruslah menegaskan dalam kontrak yang dirancang/dibuatnya bagaimana cara penyelesaian bila pada akhirnya terjadi suatu sengketa. Ketiadaan pasal yang mengatur secara tegas tentang penyelesaian sengketa ini akan berakibat berlarut-larutnya sengketa tersebut, karena mereka (para pihak) harus terlebih menyetujui bagaimana cara/ mekanisme penyelesaiannya. Sebelum hal ini disepakati, maka penyelesaian sengketa pun tidak akan terlaksana.

Sampai saat ini, penyelesaian sengketa yang diatur dalam kontrak oleh para pihak masih berkisar pada musyawarah untuk mufakat. Bila hal ini tidak dapat diselesaikan, maka penyelesaian selanjutnya diserahkan kepada lembaga kepada lembaga peradilan dalam hal ini Pengadilan Negeri, sebagaimana tempat domisili yang dipilih oleh para pihak dalam kontrak. Klausula dalam kontrak mengenai hal ini lazimnya ditulis seperti tersebut di bawah ini: 
Bilamana terdapat perselisihan atau perbedaan pendapat dalam melaksanakan perubahan perjanjian ini, maka akan diselesaikan oleh kedua belah pihak secara musyawarah/mufakat. Apabila tidak ada kata sepakat, maka mengenai perjanjian ini dan semua akibatnya, para pihak memilih tempat kediaman yang sah dan tidak berubah di Kantor Kepaniteraan Pengadilan Negeri setempat.

Sangat jarang ditemui suatu kontrak dimana dalam pasal penyelesaian sengketanya mencatumkan alternatif penyelesaian pada suatu badan arbitrase. Padahal, dengan cara ini pun suatu sengketa dapat diselesaikan dengan baik dan memuaskan para pihak, walaupun ukuran kepuasan masi sangat relatif. Untuk jelasnya, berikut disampaikan alternatif (kemungkinan) penyelesaian sengketa bagi para pihak yang berkontrak, apabila terjadi suatu perselisihan.

\section{Musyawarah/Mufakat}

Ada pertanyaan yang mungkin cukup relavan untuk dijawab di sini, yaitu: "Mengapa pada klausula penyelesaian sengketa dalam suatu kontrak selalu menempatkan musyawarah/mufakat sebagai suatu penyelesaian yang didahulukan?". Pada dasarnya penyelesaian secara musyawarah/mufakat merupakan penyelesaian yang sangat sesuai dengan kultur kita sebagai "orang timur". Namun demikian, ada satu hal yagn mungkin sangat sulit untuk mewujudkan terciptanya musyawarah/mufakat dalam suatu sengketa. Hal tersebut adalah para pihak pada umumnya menganggap remeh hal-hal yang kelihatannya sangat sepele. Justru hal-hal yang dianggap sepele oleh salah satu pihak, malah dianggap hal yang sangat materil oleh pihak lainnya. Selain itu, hal-hal sepele tersebut apabila tidak segera diselesaikan akan berakibat pada membesarnya masalah "sepele" tadi, maka terjadilah sengketa yang hampir tidak mungkin diselesaikan dengan musyawarah mufakat. Walaupun musyawarah/mufakat dianggap sebagai kultur yang hidup di masyarakat.

\section{Penutup}

\section{Kesimpulan} berikut:

Dari hasil penelitian dan pembahasan diperoleh kesimpulan sebagai

1. Agen pelayaran sebagai pengangkut bertanggung jawab terhadap kerusakan, kehilangan barang yang diangkut, apabila kerusakan dan kehilangan barang tersebut disebabkan karena kesalahan atau kelalaian dari perusahaan pengangkut, namun tidak seluruh kerugian yang diderita oleh penerima atau pengirim dapat dibebankan kepada pengangkut, apabila kerugian yang dideritanya itu nyata-nyata disebabkan oleh oleh suatu peristiwa overmatch, 
atau keadaan barang itu cacat pada waktu itu atau karena kesalahan pengirim dan ekspeditur, maka kerugian seperti itu tidak dibebankan agen pelayaran sebagai pengangkut.

2. Bahwa rasa saling percaya dan keinginan untuk saling mempertahankan hubungan baik menjadi faktor utama mendorong para pihak untuk tidak memilih jalur peradilan formal dalam setiap kali penyelesaian sengketa ganti rugi yang terjadi dalam kontrak mereka, justru sebaliknya pilihan melalui forum musyawarah dan mufakat adalah langkah yang paling tepat untuk dilakukan penyelesaian bahkan perlu dipertahankan.

3. Bahwa penyelesaian sengketa tuntutan ganti rugi dapat diselesaikan oleh pihak pengangkut, pengirim dan penerima barang dengan cara musyawarah dan mufakat di luar peradilan formal, hal ini untuk memenuhi kebutuhan para pelaku bisnis yang menuntut adanya penyelesaian sengketa yang dihadapinya dalam waktu relatif cepat, sederhana, dengan proses yang tidak bertele-tele dan dengan biaya yang relatif murah serta mempunyai kemampuan untuk menjaga kerahasian idendtitas para pihak, karena mereka beranggapan berperkara melalui peradilan formal dianggap tidak efektif hal mana berkaitan dengan jangka waktu yang dibutuhkan serta besar biaya yang harus di keluarkan.

\section{Saran}

Sebagai akhir dari artikel ini diajukan saran sebagai berikut:

1. Dengan adanya pengertian ganti rugi perlu diusahakan pengaturan yang jelas tentang tanggung jawab pengangkut dan pengirim barang yang mencerminkan tentang tanggung jawab pengangkut dan pengirim barang dalam berat dan ringannya tanggung jawab tersebut secara tegas dan mencegah keraguan-keraguan serta kesimpangsiuran, sedangkan batas nilai tanggung jawab ganti rugi perlu memperhatikan dan memperhitungkan nilai-nilai ekonomi secara wajar.

2. Diupayakan adanya suatu tingkat pemahaman di kalangan pihak pengangkut maupun pengguna jasa EMKL dan perusahaan jasa bongkar muat untuk mempelajari pengetahuan-pengetahuan tentang peraturan-peraturan yang berkaitan dengan perjanjian pengangkutan laut khususnya ganti rugi, mengingat sampai saat sesuai dengan hasil penelitian bahwa pihak-pihak tersebut diatas kurang memiliki pengetahuan-pengetahuan tersebut di atas, sehingga mereka tidak mengetahui dengan jelas apa yang menjadi hak dan kewajiban mereka sebagai pihak-pihak yang terlibat dalam perjanjian tersebut.

3. Bahwa forum penyelesaian sengketa ganti rugi pengangkutan barang melalui cara musyawarah dan mufakat adalah jawaban untuk memenuhi kebutuhan para pihak yang terkait perlu kiranya dikembangkan lebih lanjut dan dapat disosialisasikan, karena 
dengan forum ini, maka para pihak dapat menyelesaikan permasalahan secara cepat, murah dan tidak menimbulkan ketersinggungan antara kedua belah pihak dengan kata lain penyelesaian bisa lebih efektif dan ekonomis serta lebih terarah jika dibandingkan penyelesaian melalui peradilan formal, bahkan bagi agen pelayaran yang peduli terhadap pelanggan, maka tuntutan ganti rugi tetap dipenuhi walaupun pihaknya mengalami untung tipis, namun dengan pertimbangan agar langgananya (claimant) itu tetap menjadi langganannya, artinya supaya mereka tidak beralih kepada maskapai pelayaran yang lain, maka pembayaran ganti rugi bukan menjadi masalah, namun yang terpenting adalah demi menjaga hubungan baik dengan pelanggan, dengan demikian hubungan baik itu disebut Ex Gratia Payment, yaitu membayar walaupun untung tipis, dengan cara ini perusahaan pelayaran akan lebih banyak mempunyai langganan. ${ }^{17}$

${ }^{17}$ Hasil Wawancara dengan Drs. Buala F. Zendrato, Branch Manager PT. Admiral Lines Belawan, tanggal 20 Maret 2002. 


\section{Daftar Pustaka}

Amir, M.S, Pengetahuan Bisnis Ekspor Impor, Seri Umum No. 8, Jakarta: Pustaka Binaman Pressindo, 1992.

Letter of Credit Dalam Bisnis Ekspor Impor, Jakarta: Pustaka Binaman Pressindo, 1996.

Lubis, M. Solih. Hukum Nasional Dalam Era PJPT II, Makalah Mata Kuliah Politik Hukum, Pascasarjana, Universitas Sumatra Utara, Medan, 1999.

Muhammad, Abdul kadir. Hukum Perikatan, Bandung: Alumni, 1982.

Purwosutjipto. Pengertian Pokok Hukum Dagang Indonesia, jilid III, Jakarta: Djambatann, 1987.

Subekti, R. Pokok-Pokok Hukum Perdata, Jakarta: PT. Internusa, 1979.

Sukardono. Hukum Dagang Indonesia, Jilid II, Bagian I, Hukum Pengankutan, Jakarta: Soerangan, 1961.

Soedjatmiko, FDC. Pokok-Pokok Pelayaran Niaga, Jakarta: Akademi Pressindo, 1985.

Soedjono, Wiwoho. Hukum Laut Khusus Tentang Pengangkutan Barang Di Indonesia, Yogyakarta: Liberty, 1986.

Siregar Muchtaruddin. Beberapa Masalah Ekonomi Dan Manajemen

Pengangkutan, Jakarta: Lembaga Peneliti Fakultas Ekonomi Universitas Indonesia, 1990.

Sukardiman, Tjuk. Sambutan Dirjen Hubla, Peluncuran Buku Hukum dan Masalah-Masalah Pelayaran di Indonesia, Jakarta: Pustaka Sinar Harapan, 2001.

Siregar, Hasnil Basri. Kapita Selekta Hukum Laut Dagang, Kelompok Studi Hukum Masyarakat FH. Universitas Sumatera Utara, Medan, 1993.

Salim, Abbas, H.A. Manajemen Pelayaran Niaga dan Pelabuhan, Jakarta: Pustaka Jaya, 1995.

Subandi. Penentuan Claim Angkutan Laut, Jakarta: Arcan, 1989.

Umar, M. Husseyn. Hukum Maritim dan Masalah-Masalah Pelayaran di Indonesia, Jakarta: Pustaka Sinar Harapan, 2001.

Zendrato, Buala F. Branch Manager PT. Admiral Lines Belawan, Wawancara, tanggal 20 Maret 2002. 